\title{
PENGARUH DISIPLIN DAN MOTIVASI TERHADAP KINERJA GURU DI SMP NEGERI 2 KEJURUAN MUDA KABUPATEN ACEH TAMIANG
}

\author{
Rasman $^{1}$, Sofyan ${ }^{2}$, Dedy Suhery ${ }^{3}$, Syarifah Hanim ${ }^{4}$ \\ ${ }^{1}$ SDN 1 Bukit Rata Kuala Simpang, Kab Aceh Tamiang, ${ }^{2}$ Sekolah Tinggi Agama Islam \\ Darul Arafah Deli Serdang, ${ }^{3}$ IAIN Langsa, ${ }^{4}$ SDN2 Seulalah Kota Langsa \\ ${ }^{1}$ rasmansp@gmail.com, ${ }^{2}$ Sofyanma543@gmail.com, ${ }^{3}$ Suheyassilmy@ gmail.com,
}

${ }^{4}$ Ipahcakep4@gmail.com

\begin{abstract}
Abstrak
Tujuan dari penelitian ini adalah: (1) untuk mengetahui dan menganalisis pengaruh disiplin terhadap kinerja Guru di SMP Negeri 2 Kejuruan Muda Kabupaten Aceh Tamiang, (2) untuk mengetahui dan menganlisis pengaruh motivasi terhadap kinerja Guru di SMP Negeri 2 Kejuruan Muda Kabupaten Aceh Tamiang, (3) untuk mengetahui pengaruh disiplin dan motivasi terhadap Kinerja Guru. Teknik pengumpulan data menggunakan metode non tes, dengan instrumen penelitian angket dan studi perpustakaan. Analisis data menggunakan SPSS dengan analisis deskriptif dan analisis regresi. Hasil penelitian menunjukkan bahwa terdapat pengaruh positif dan signifikan Disiplin terhadap Kinerja Guru SMP Negeri 2 Kejuruan Muda Kabupaten Aceh Tamiang sebesar 0,797 terhadap Kinerja Guru sehingga dapat di simpulkan Disiplin yang memadai dapat menentukan Kinerja Guru juga akan tinggi walaupun ada variable lain yang mendukung untuk melihat hasil kinerja seorang Guru. Terdapat pengaruh positif tetapi tidak signifikan Motivasi terhadap Kinerja Guru SMP Negeri 2 Kejuruan Muda Kabupaten Aceh Tamiang sebesar 0,022 terhadap Kinerja Guru sehingga dapat di simpulkan Motivasi yang memadai dapat menentukan Kinerja Guru juga akan tinggi walaupun ada variabel lain yang mendukung untuk melihat hasil kinerja seorang Guru. Secara simultan dapat dilihat bahwa variabel independen Disiplin dan Motivasi memiliki nilai signifikan $\alpha(0,000$ $<0,05$ dan nilai fhitung > ftabel (89,277 > 3,32). Sehingga dapat disimpulkan bahwa variabel Disiplin dan Motivasi berpengaruh secara signifikan dan simultan terhadap Kinerja Guru. Sehingga hal ini berarti semakin tinggi Disiplin dan Motivasi semakin baik pula Kinerja Guru. Dan sebaliknya semakin rendah Disiplin dan Motivasi maka Kinerja Guru semakin kurang baik.
\end{abstract}

Kata Kunci : Disiplin, Motivasi, dan Kinerja Guru

\section{PENDAHULUAN}

Pendidikan merupakan sarana yang sangat strategis dalam meningkatkan kualitas sumber daya manusia yang merupakan factor determinan pembangunan. Pendidikan adalah usaha sadar untuk menyiapkan peserta didik melalui kegiatan bimbingan, pengajaran dan atau latihan bagi peranannya di masa yang akan datang ${ }^{1}$.

1 Hukumonline, "Undang-Undang Nomor 20 Tahun 2003 - Pusat Data Hukumonline," hukumonline.com, diakses 13 Januari 2022, https://hukumonline.com/pusatdata/detail/13662/undangundangnomor-20-tahun-2003/document.

Al Qalam: Jurnal Ilmiah Keagamaan dan Kemasyarakatan Vol. 16, No. 1 Januari - Juni 2022 
Kinerja merupakan sesuatu yang ingin dicapai, prestasi yang diperlihatkan dan kemampuan kerja seseorang. Guru selain berperan sebagai pengajar juga merupakan pendidik serta pelaksana sebagian tugas administrasi sekolah karena itu sering juga dikatakan guru sebagai programmer, administrator, fasilitator, dan evaluator dalam lingkungan sekolah. Dengan peran-peran seperti itu beban tugas guru sehari-hari disamping mengajar lebih banyak tertumpu pada hal-hal yang bersifat teknik administrative seperti memeriksa lembar kerja siswa dengan memberi catatan dan penilaian, membuat soal ulangan ujian, mengelola nilai dan mengelola absen. kinerja adalah Hasil kerja secara kualitas dankuantitas yang dicapai oleh pegawai dalam melakukan tugas-tugasnya sesuai dengan tanggung jawab yang diberikan ${ }^{2}$.

Motivasi kerja adalah sesuatu yang menimbulkan semangat atau dorongan kerja. Oleh sebab itu, motivasi kerja dalam psikologi sebagai pendorong semangat kerja ${ }^{3}$. Guru menjadi seorang pendidik karena adanya motivasi untuk mendidik. Bila tidak mempunyai motivasi maka ia tidak akan berhasil untuk mendidik atau mengajar. Keberhasilan guru dalam mengajar karena dorongan atau motivasi ini sebagai pertanda apa yang dilakukan oleh guru yang diminatinya karena sesuai dengan kepentingannnya sendiri. Guru yang termotivasi dalam bekerja akan menimbulkan kepuasan kerja, karena kebutuhan-kebutuhan guru yang terpenuhi mendorong guru untuk meningkatkan kinerjanya

Disiplin juga merupakan salah satu indikator atau faktor yang mempengaruhi dalam meningkatkan kinerja mengajar guru. Warsidi dan Pramuka (2000), mengemukakan bahwa kedisiplinan adalah fungsi operatif keenam dari Manajemen Sumber Daya Manusia ${ }^{4}$. Disiplin merupakan fungsi operatif yang terpenting karena semakin baik disiplin seorang guru, maka semakin tinggi prestasi kerja yang dapat dicapainya. Disiplin yang baik mencerminkan besarnya tanggung jawab seseorang terhadap tugas-tugas yang diberikan kepadanya. Disiplin adalah kesadaran dan kesediaan seseorang menaati semua peraturan perusahaan dan norma-norma sosial.

Ketidaksiplinan dari segi waktu menunjukkan sikap yang kurang baik diperlihatkan pada peserta didik karena sikap yang baik di mulai dari pendidik terlebih dahulu. Suatu sikap disiplin haruslah diterapkan lewat tingkah laku yang selalu taat terhadap peraturan yang berlaku. Sikap ini diharapkan akan berdampak pada peningkatan kinerja guru itu sendiri serta berdampak pula pada peningkatan mutu dan prestasi peseta didik.

Akan tetapi, permasalahan disiplin kerja yang masih sering terjadi diantaranya adalah kurangnya kedisiplinan guru terhadap peraturan yang telah ditentukan berkaitan dengan waktu datang maupun pulang kerja, masih terdapat beberapa guru yang tidak memberikan kabar (tanpa keterangan) ketika berhalangan hadir, masih terdapat guru yang datang terlambat masuk sekolah atau pun masuk kelas untuk mengajar ,masih ada guru yang belum lengkap menyusun perangkat pembelajaran seperti program tahunan, program

${ }^{2}$ Mangkunegara Anwar Prabu, Evaluasi Kinerja Sumber Daya Manusia (Bandung: PT Refika Aditama, 2009).

${ }^{3}$ Anoraga Pandji, Psikologi Kerja (Jakarta: Rineka Cipta, 1998), 35.

${ }^{4}$ Warsidi dan Pramuka, Pemahaman Ekonomi Umum (Jakarta: PT. Gramedia Pustaka Umum, 2000).

Al Qalam: Jurnal Ilmiah Keagamaan dan Kemasyarakatan Vol. 16, No. 1

Januari - Juni 2022 
semester, analisis ulangan harian, remedial dan sebagainya. dan beberapa guru honorer tidak membuat atau tidak memiliki RPP dan tidak melakukan penilaian proses pembelajaran secara rutin (sumber hasil supervisi Wakil Kepala Sekolah). Keadaan ini merupakan cermin dimana disiplin kerja yang dimiliki oleh dewan guru masih jauh dari harapan.

Berdasarkan uraian di atas bahwa disiplin waktu dalam mengajar sangat berdampak pada kinerja guru khususnya dalam mengajar atau mendidik siswa atau peserta didiknya, motivasi sebagai suatu kekuatan potensial yang ada dalam diri seseorang manusia khususnya sebagai guru yang dapat dikembangkannya sendiri atau dikembangkan oleh sejumlah kekuatan luar yang dimiliki seorang tenaga pendidik. fenomena yang di dapatkan di lapangan seperti disiplin yang diterapkan oleh guru masih belum terlaksana dengan baik seperti masih adanya guru yang datang lambat dan pulang cepat, pelatihan dan workshop yang diikuti oleh guru masih kurang selain itu kompetensi belum terlaksana dengan baik, olehnya fenomena tersebut dapat dijadikan alasan memilih lokasi SMP Negeri 2 Kejuruan Muda Kabupaten Aceh Tamiang sebagai lokasi penelitian.

\section{KAJIAN TEORI}

Disiplin merupakan kontrol diri dan tingka laku tertata karyawan dan mengindikasikan adanya tim kerja yang sejatinya di dalam organisasi. kedisiplinan adalah kesadaran dan kesediaan seseorang menaati semua peraturan perusahaan dan norma-norma yang berlaku ${ }^{5}$. Kesadaran adalah sikap seseorang yang secara sukarela mentaati semua peraturan dan sadar akan tugas dan tanggung jawabnya, jadi dia akan mematuhi / mengerjakan semua tugasnya dengan baik, bukan atas paksaan. Sedangkan yang dimaksud dengan kesediaan adalah suatu sikap, tingkah laku dan perbuatan seseorang yang sesuai dengan peraturan perusahaan, baik yang tertulis maupun tidak.

Disiplin kerja adalah suatu alat yang digunakan para manajer untuk berkomunikasi dengan karyawan agar mereka bersedia untuk mengubah suatu perilaku serta sebagai suatu upaya untuk meningkatkan kesadaran dan kesediaan seseorang mentaati semua peraturan perusahaan dan norma-norma sosial yang berlaku (Rivai, 2011). Disiplin kerja pada dasarnya selalu diharapkan menjadi ciri setiap sumber daya manusia dalam organisasi, karena dengan kedisplinan organisasi akan berjalan dengan baik dan bisa mencapai tujuannya dengan baik pula. Disiplin kerja mempunyai pengaruh positif terhadap kinerja guru. Guru yang disiplin dalam bekerja sejak berangkat, saat kerja dan saat pulang kerja serta sesuai aturan dalam bekerja, biasanya akan memiliki kinerja yang baik. Dapat disimpulkan, semakin tinggi disiplin kerja, maka semakin tinggi kinerja guru. Berdasarkan pengertian di atas disimpulkan bahwa disiplin kerja merupakan suatu sikap, tingkah laku, dan perbuatan yang sesuai dengan peraturan baik tertulis maupun tidak tertulis, dan bila melanggar akan ada sanksi atas pelanggarannya.

${ }^{5}$ Hasibuan, Organisasi Dan Motivasi Dasar Peningkatan Produktivitas, vol. 7 (Jakarta: Bumi Aksara, 2012), 14.

Al Qalam: Jurnal Ilmiah Keagamaan dan Kemasyarakatan Vol. 16, No. 1 Januari - Juni 2022 
Rasman, Sofyan, Dedy Suhery, Syarifah Hanim : Pengaruh Disiplin dan Motivasi Terhadap Kinerja Guru di SMP Negeri 2 Kejuruan Muda Kabupaten Aceh Tamiang

Motivasi berasal dari kata dasar motif, yang mempunyai arti suatu perangsang, keinginan dan daya penggerak kemauan bekerja seseorang ${ }^{6}$. Motivasi adalah pemberian daya penggerak yang menciptakan kegairahan kerja seseorang agar mereka mau bekerjasama dengan efektif dan terintegrasi dengan segala daya upayanya untuk mencapai kepuasan.

Motivasi adalah kesediaan untuk mengeluarkan tingkat upaya yang tinggi untuk tujuan organisasi yang dikondisikan oleh kemampuan upaya itu dalam memenuhi beberapa kebutuhan individual ${ }^{7}$. Kebutuhan terjadi apabila tidak ada keseimbangan antara apa yang dimiliki dan apa yang diharapkan. Dorongan merupakan kekuatan mental yang berorientasi pada pemenuhan harapan dan pencapaian tujuan. Dan tujuan adalah sasaran atau hal yang ingin dicapai oleh seseorang individu.

Motivasi kerja adalah kondisi yang berpengaruh membangkitkan, mengarahkan dan memelihara perilaku yang berhubungan dengan lingkungan kerja ${ }^{8}$. Motivasi kerja adalah suatu kekuatan potensial yang ada dalam diir seorang manusia, yang dapat dikembangkan oleh sejumlah kekuatan luar yang ada padi intinya berkisar sekitar imbalan moneter dan imbalan non meter yang dapat mempengaruhi hasil kinerjanya secara pasif atau secara negatif, hal mana tergantung pada situasi dan kondisi yang dihadapi orang yang bersangkutan ${ }^{9}$.

\section{Definisi Kinerja Guru}

Kinerja diartikan sebagai tindakan nyata pada kemampuan seseorang yang mengacu pada tujuan organisasi. kinerja (performance) pada dasarnya adalah apa yang dilakukan atau tidak dilakukan oleh karyawan ${ }^{10}$. Kinerja karyawan yang umum untuk kebanyakan pekerjaan meliputi: elemen kuantitas dari hasil, kualitas dari hasil, ketepatan waktu dari hasil, kehadiran, dan kemampuan bekerja sama." Menurut Kamus Besar Bahasa Indonesia "kinerja adalah: (1) sesuatu yang dicapai; (2) prestasi yang diperlihatkan; (3) kemampuan kerja (peralatan)." Kinerja apabila dihubungkan dengan aktivitas guru, maka kinerja guru adalah "tampilan aktivitas guru yang dinilai berdasarkan tugas dan tanggung jawab profesionalnya pada kurun waktu tertentu ${ }^{11}$."

Guru perlu menguasai kompetensi agar mendukung kinerjanya menjadi tinggi. Direktorat Tenaga Kependidikan Depdiknas menyatakan bahwa secara keseluruhan kompetensi guru terdiri dari tujuh, yaitu: penyusunan rencana pembelajaran, pelaksanaan interaksi belajar mengajar, penilaian prestasi belajar peserta didik, pelaksanaan tindak

\footnotetext{
${ }^{6}$ Hasibuan, Proses Belajar Mengajar (Bandung: PT Rosda karya, 2011), 95.

${ }^{7}$ Robbins, Perilaku Organisasi Konsep Kontroversi Aplikasi. Edisi Bhs. Indonesia (Jakarta: PT. Prenhallindo, 2001), 166.

${ }^{8}$ Handoko, Manajemen, vol. 2 (Yogyakarta: BPFE, 2001), 77.

${ }^{9}$ Winardi, J, Manajemen Perilaku Organisasi (Jakarta: Kencana Prenada Media Group, 2004), 6.

${ }^{10}$ J.H Jackson dan Mathis, R.L, Human Resource Management: Manajemen Sumber Daya Manusia, trans. oleh Dian Angelia (Jakarta: Salemba Empat, 2008), 378.

${ }^{11}$ Hasibuan, Proses Belajar Mengajar, 164-65.
}

Al Qalam: Jurnal Ilmiah Keagamaan dan Kemasyarakatan Vol. 16, No. 1 Januari - Juni 2022 
lanjut hasil penilaian prestasi belajar peserta didik, pengembangan profesi, pemahaman wawasan pendidikan, serta penguasaan bahan kajian akademik ${ }^{12}$.

Berdasarkan pada definisi tersebut, kinerja guru ialah tindakan yang menggambarkan hasil kerja seorang guru yang mengacu pada tujuan pendidikan, berhubungan dengan bidang mengajar, mendidik, dan melatih peserta didik yang dimulai dari kegiatan perencanaan pembelajaran, pelaksanaan pembelajaran, dan evaluasi pembelajaran.

\section{Kinerja Guru yang Efektif}

Empat karakteristik dari mengajar yang efisien adalah: (1) penampilan mengajar (penguasaan bahan ajar), persiapan mengajar, dan sebagainya; (2) cara mengajar (pemilihan model instruksi, alat bantu mengajar, dan evaluasi yang dipakai); (3) kompetensi dalam mengajar; (4) pengambilan keputusan yang bijaksana ${ }^{13}$. Profil guru yang efektif di sekolah dapat ditunjukkan dengan: (1) guru yang efektif dapat menciptakan pembelajaran yang kondusif sehingga membuat murid dapat belajar; (2) guru mengikuti seminar lokakarya tentang pendidikan Sekolah Dasar; (3) guru senang mengakses informasi dari mass media; (4) guru dapat menumbuhkan sikap dan perilaku positif pada peserta didik. Adapun guru yang profesional meliputi kemampuan dalam ${ }^{14}$ :

1) Menguasai kurikulum serta perangkat pedoman pelaksanaannya.

2) Menguasai materi mata pelajaran yang harus diajarkan.

3) Mampu mengembangkan dan menggunakan berbagai metode yang bervariasi.

4) Mampu mengembangkan dan menggunakan berbagai macam media pembelajaran.

5) Terampil menyelenggarakan evaluasi proses dan hasil belajar.

6) Memiliki rasa taggung jawab dan dedikasi guru terhadap tugasnya, serta disiplin dalam melaksanakan tugasnya.

\section{METODE PENELITIAN}

Pendekatan dalam penelitian ini adalah pendekatan kuantitatif deskriptif. Penelitian Kuantitatif merupakan metode penelitian yang lebih menekankan pada aspek pengukuran secara objektif terhadap fenomena sosial. Untuk melakukan pengukuran, setiap fenomena sosial dijabarkan dalam beberapa komponen masalah, variable dan indikator. Tujuan penelitian kuantitatif yaitu untuk mengembangkan dan menggunakan model-model matematis, teori-teori atau hipotesis yang berkaitan dengan fenomena alam. Cara yang digunakan adalah melalui metode asosiatif dan kausal. Populasi adalah wilayah generalisasi yang terdiri dari objek dan subjek yang mempunyai kriteria dan karakteristik tertentu yang ditetapkan oleh peneliti dan mempunyai kesempatan yang sama untuk dipilih menjadi

12 Kunandar, Guru Profesional Implementasi Kurikulum Tingkat Satuan Pendidikan (KTSP) dan Persiapan Menghadapi Sertifikasi Guru (Jakarta: PT Raja Grafindo Persada, 2007), 56.

${ }^{13}$ Kunandar, 39.

${ }^{14}$ Ibrahim Bafadal, Manajemen Perlengkapan Sekolah Teoridan Aplikasinya (Jakarta: Bumi Aksara, 2008), 21-22.

Al Qalam: Jurnal Ilmiah Keagamaan dan Kemasyarakatan Vol. 16, No. 1 Januari - Juni 2022 
anggota sampel ${ }^{15}$. Populasi dari penelitian ini adalah seluruh guru di SMP Negeri 2 Kejuruan Muda kabupaten Aceh Tamiang sebanyak 32 orang .sedangkan sampel adalah bagian dari populasi yang mempunyai peluang/estimasi yang sama untuk menjadi sampel ${ }^{16}$. Oleh karena itu, dengan teknik penarikan sampel secara total sampling, maka sampel dalam penelitian ini berjumlah 32 orang guru SMP Negeri 2 Kejuruan Muda Kabupaten Aceh Tamiang. Adapun Jenis dan sumber data yang digunakan dalam penelitian ini dapat dikelompokkan menjadi dua kategori yaitu: Data primer dan data sekunder. Sedangkan teknik pengumpulan data melalui wawancara, kuesioner dan studi kepustakaan.

Teknik Analisis Data melalui uji kualitas data dengan uji validasi dan uji reliabilitas a. Uji Validitas Uji

Validitas digunakan untuk mengukur sah atau valid tidaknya suatu kuesioner. Suatu kuesioner dikatakan valid jika pertanyaan pada kuesioner mampu untuk mengungkapkan sesuatu yang akan diukur oleh kuesioner tersebut. Metode yang digunakan untuk menguji validitas adalah melakukan korelasi antar skor butir pertanyaan dengan total skor konstruk atau variabel. Pengujian validitas dilakukan dengan melakukan korelasi bilvariate antara masing-masing skor indikator dengan total skor konstruk. Hasil analisis korelasi bilvariate dengan melihat output Pearson Correlation, dengan ketentuan:

1) $r$ hitung $>r$ tabel, maka instrumen yang digunakan dinyatakan valid.

2) $r$ hitung $<\mathrm{r}$ tabel, maka instrumen yang digunakan dinyatakan tidak valid.

b. Uji Reliabilitas

Uji reliabilitas sebenarnya adalah alat untuk mengukur suatu kuesioner yang merupakan indikator dari variabel atau konstruk. Suatu kuesioner dikatakan reliable atau handal jika jawaban seseorang terhadap pernyataan adalah konsisten atau stabil dari waktu ke waktu. Reliabilitas dapat dilakukan dengan dua cara yaitu ${ }^{17}$ :

1) Repeated Measure arau pengukuran ulang

Disini seseorang akan disodori pertanyaan yang sama pada waktu yang berbeda, dan kemudian dilihat apakah ia tetap konsisten dengan jawabannya.

2) One Shot atau pengukuran sekali saja

Disini pengukurannya hanya sekali saja dan kemudian hasilnya dibandingkan dengan pertanyaan lain atau mengukur korelasi antar jawaban pertanyaan. Program SPSS yang memberikan fasilitas untuk mengukur reliabilitas dengan uji statistik Cronbach Alpha. Suatu konstruk atau variabel dikatakan reliabel jika memberikan nilai Cronbach Alpha > 0,60. Dalam penelitian ini menggunakan one shot supaya lebih efisien dalam waktu penyelesaian penelitian.

\section{HASIL DAN PEMBAHASAN}

Karakteristik Responden

\footnotetext{
${ }^{15}$ Arikunto, Metode Penelitian Pendidikan Pendekatan Kuantitatif, Kualitatif dan R\&D (Bandung: Alfabeta, 2002), 98.

16 Arikunto, 99.

17 Triton, Prosedur Penelitian Suatu Pendekatan Pratik (Jakarta: Rineka Cipta, 2002), 57.
}

Al Qalam: Jurnal Ilmiah Keagamaan dan Kemasyarakatan Vol. 16, No. 1 Januari - Juni 2022 
Rasman, Sofyan, Dedy Suhery, Syarifah Hanim : Pengaruh Disiplin dan Motivasi Terhadap Kinerja Guru di SMP Negeri 2 Kejuruan Muda Kabupaten Aceh Tamiang

a. Identitas Responden Bedasarkan Golongan

Tabel 3.1 Identitas Responden Berdasarkan Golongan

\begin{tabular}{|l|l|l|l|}
\hline No & Golongan & Jumlah & Persentase \\
\hline 2 & Golongan III & 22 & 68.75 \\
\hline 3 & Golongan IV & 10 & 31.25 \\
\hline \multicolumn{2}{|l|}{ To t a l } & 32 & 100.00 \\
\hline
\end{tabular}

Sumber : SMP Negeri 2 Kejuruan Muda Kabupaten Aceh Tamiang.

Dari Tabel 3.1. diatas dapat dijelaskan bahwa responden golongan III berjumlah 22 orang 68,75, golongan IV berjumlah 10 orang $31,25 \%$.

b. Identitas Responden Berdasarkan Jenis Kelamin

Tabel 3.2 Identitas Responden Berdasarkan Jenis Kelamin

\begin{tabular}{|l|l|l|l|}
\hline No & Jenis Kelamin & Jumlah & Persentase \\
\hline 1 & Laki-laki & 23 & 71.87 \\
\hline 2 & Perempuan & 9 & 28.12 \\
\hline \multicolumn{2}{|l|}{ T o t a 1} & 32 & 100.00 \\
\hline
\end{tabular}

Sumber : SMP Negeri 2 Kejuruan Muda Kabupaten Aceh Tamiang.

Berdasarkan pada Tabel 3.2 diketahui bahwa jumlah laki - laki yang menjadi responden pada penelitian ini adalah 32 orang. Responden laki-laki pada penelitian ini adalah 23 orang atau sama dengan sebesar $71,87 \%$. Responden perempuan pada penelitian ini adalah sebesar 9 orang atau sama dengan 28,12\%. Ini menunjukkan bahwa yang menjadi responden pada penelitian ini yang paling besar adalah laki - laki atau dengan kata lain, bahwa Guru di SMP Negeri 2 Kejuruan Muda Kabupaten Aceh Tamiang didominasi oleh laki-laki.

c. Identitas Responden Berdasarkan Jenjang Pendidikan

Tabel 3.3 Identitas Responden Berdasarkan Jenjang Pendidikan

\begin{tabular}{|l|l|l|l|}
\hline No & Pendidikan & Jumlah & Persentase \\
\hline 3 & S1 & 24 & 75.00 \\
\hline 4 & S2 & 8 & 25.00 \\
\hline \multicolumn{2}{|l|}{ T o t a l } & 32 & 100.00 \\
\hline
\end{tabular}

Sumber : SMP Negeri 2 Kejuruan Muda Kabupaten Aceh Tamiang.

Tabel 3.3 menjelaskan bahwa pada tingkat pendidikan Sarjana/S1 adalah sebanyak 24 orang atau sama dengan 75,00\%. Responden dengan tingkat pendidikan Pascasarjana/S2 adalah sebanyak 8 orang atau sama dengan $25,00 \%$.

\section{Penjelasan Responden Atas Variabel Penelitian}

Untuk memberikan gambaran yang jelas sehubungan dengan jawaban - jawaban dari responden sehubungan dengan variabel penelitian ini dapat dijelaskan sebagai berikut: a. Penjelasan Responden Atas Variabel Disiplin (X1)

Untuk melihat gambaran distribusi jawaban responden pada setiap kuesioner pertanyaan pada variabel Disiplin dapat dijelaskan sebagai berikut:

Tabel 3.4 Penjelasan Responden Atas Disiplin

Al Qalam: Jurnal Ilmiah Keagamaan dan Kemasyarakatan Vol. 16, No. 1

Januari - Juni 2022 
Rasman, Sofyan, Dedy Suhery, Syarifah Hanim : Pengaruh Disiplin dan Motivasi Terhadap Kinerja Guru di SMP Negeri 2 Kejuruan Muda Kabupaten Aceh Tamiang

\begin{tabular}{|l|l|l|l|l|l|l|l|l|l|l|}
\hline \multirow{2}{*}{ Kuesioner } & \multicolumn{9}{|c|}{$\begin{array}{l}\text { Sangat } \\
\text { Setuju }\end{array}$} & \multicolumn{3}{|l|}{$\begin{array}{l}\text { Setuju } \\
\text { Setuju }\end{array}$} \\
\cline { 2 - 13 } & F & $\%$ & F & $\%$ & F & $\%$ & F & $\%$ & F & $\%$ \\
\hline 1 & 18 & 20.15 & 10 & 10.19 & 4 & 4.30 & 0 & 0 & 0 & 0 \\
\hline 2 & 16 & 17.40 & 16 & 17.40 & 0 & 0 & 0 & 0 & 0 & 0 \\
\hline 3 & 17 & 18.19 & 10 & 10.19 & 5 & 5.19 & 0 & 0 & 0 & 0 \\
\hline 4 & 14 & 15.50 & 12 & 13.35 & 2 & 2.57 & 0 & 0 & 0 & 0 \\
\hline 5 & 19 & 20.76 & 11 & 12.81 & 4 & 4.30 & 0 & 0 & 0 & 0 \\
\hline 6 & 12 & 13.35 & 15 & 15.35 & 1 & 1.35 & 0 & 0 & 0 & 0 \\
\hline 7 & 12 & 13.35 & 13 & 13.65 & 4 & 4.30 & 0 & 0 & 0 & 0 \\
\hline 8 & 11 & 12.81 & 12 & 13.35 & 5 & 5.19 & 0 & 0 & 0 & 0 \\
\hline 9 & 9 & 19.35 & 15 & 15.35 & 2 & 2.57 & 0 & 0 & 0 & 0 \\
\hline 10 & 10 & 10.19 & 12 & 13.35 & 3 & 3.35 & 0 & 0 & 0 & 0 \\
\hline Rata-Ratak \\
\hline
\end{tabular}

Tabel 3.4 menunjukkan pada variabel Disiplin bahwa guru sudah melaksanakan dengan baik, dimana responden rata - rata yang menyatakan sangat setuju adalah sebanyak 15 orang atau sama dengan $46,87 \%$. Responden yang menyatakan setuju adalah sebanyak 12 orang atau sama dengan $37,50 \%$. Responden yang menyatakan kurang setuju adalah sebanyak 5 orang atau sama dengan $15.62 \%$.

\section{b. Penjelasan Responden Atas Motivasi (X2)}

Untuk melihat gambaran distribusi jawaban responden pada setiap kuesioner pertanyaan pada variabel Motivasi dapat dijelaskan sebagai berikut:

Tabel 3.5 Penjelasan Responden Atas Variabel Motivasi

\begin{tabular}{|c|c|c|c|c|c|c|c|c|c|c|}
\hline \multirow[t]{2}{*}{ Kuesioner } & \multicolumn{2}{|c|}{$\begin{array}{l}\text { Sangat } \\
\text { Setuju }\end{array}$} & \multicolumn{2}{|c|}{ Setuju } & \multicolumn{2}{|c|}{$\begin{array}{l}\text { Kurang } \\
\text { Setuju }\end{array}$} & \multicolumn{2}{|c|}{$\begin{array}{l}\text { Tidak } \\
\text { Setuju }\end{array}$} & \multicolumn{2}{|c|}{$\begin{array}{l}\text { Sangat Tidak } \\
\text { Setuju }\end{array}$} \\
\hline & $\mathrm{F}$ & $\%$ & $\mathrm{~F}$ & $\%$ & $\mathrm{~F}$ & $\%$ & $\mathrm{~F}$ & $\%$ & $\mathrm{~F}$ & $\%$ \\
\hline 1 & 28 & 27.38 & 20 & 20.48 & 10 & 10.19 & 0 & 0 & 0 & 0 \\
\hline 2 & 27 & 25.00 & 15 & 16.43 & 5 & 5.62 & 0 & 0 & 0 & 0 \\
\hline 3 & 28 & 20.24 & 12 & 12.95 & 7 & 7.86 & 0 & 0 & 0 & 0 \\
\hline 4 & 24 & 26.19 & 10 & 10.19 & 6 & 6.19 & 0 & 0 & 0 & 0 \\
\hline 5 & 25 & 26.19 & 11 & 11.90 & 12 & 12.76 & 0 & 0 & 0 & 0 \\
\hline 6 & 29 & 23.81 & 8 & 8.52 & 8 & 8.33 & 0 & 0 & 0 & 0 \\
\hline 7 & 22 & 23.81 & 15 & 16.43 & 7 & 7.86 & 0 & 0 & 0 & 0 \\
\hline 8 & 23 & 16.67 & 5 & 5.62 & 10 & 10.19 & 0 & 0 & 0 & 0 \\
\hline 9 & 19 & 20.24 & 6 & 6.43 & 5 & 5.62 & 0 & 0 & 0 & 0 \\
\hline 10 & 21 & 25.00 & 10 & 10.19 & 4 & 4.86 & 0 & 0 & 0 & 0 \\
\hline
\end{tabular}

Al Qalam: Jurnal Ilmiah Keagamaan dan Kemasyarakatan Vol. 16, No. 1 Januari - Juni 2022 
Rasman, Sofyan, Dedy Suhery, Syarifah Hanim : Pengaruh Disiplin dan Motivasi Terhadap Kinerja Guru di SMP Negeri 2 Kejuruan Muda Kabupaten Aceh Tamiang

\begin{tabular}{|l|l|l|l|l|l|l|l|l|l|l|}
\hline Rata-Rata & 13 & 40.62 & 12 & 37.50 & 7 & 21,87 & 0 & 0 & 0 & 0 \\
\hline
\end{tabular}

Tabel 3.5 menunjukkan variable Motivasi sudah dilaksanakan dengan baik, dimana responden rata - rata yang menyatakan sangat setuju adalah sebanyak 13 orang atau sama dengan 40,62 \%. Responden yang menyatakan setuju adalah sebanyak 12 orang atau sama dengan $37,50 \%$. Responden yang menyatakan kurang setuju adalah sebanyak 7 orang atau sama dengan $21.87 \%$.

\section{c. Penjelasan Responden Atas Variabel Kinerja Guru (Y)}

Untuk melihat gambaran distribusi jawaban responden pada setiap kuesioner pertanyaan pada variabel Kinerja Guru dapat dijelaskan sebagai berikut:

Tabel 3.6 Penjelasan Responden Atas Variabel Kinerja Guru

\begin{tabular}{|c|c|c|c|c|c|c|c|c|c|c|}
\hline \multirow[t]{2}{*}{ Kuesioner } & \multicolumn{2}{|c|}{$\begin{array}{l}\text { Sangat } \\
\text { Setuju }\end{array}$} & \multicolumn{2}{|c|}{ Setuju } & \multicolumn{2}{|c|}{$\begin{array}{l}\text { Kurang } \\
\text { Setuju }\end{array}$} & \multicolumn{2}{|c|}{$\begin{array}{l}\text { Tidak } \\
\text { Setuju }\end{array}$} & \multicolumn{2}{|c|}{$\begin{array}{ll}\text { Sangat } & \text { Tidak } \\
\text { Setuju } & \end{array}$} \\
\hline & $\mathrm{F}$ & $\%$ & $\mathrm{~F}$ & $\%$ & $\mathrm{~F}$ & $\%$ & $\mathrm{~F}$ & $\%$ & $\mathrm{~F}$ & $\%$ \\
\hline 1 & 20 & 21.19 & 26 & 28.57 & 10 & 10.19 & 0 & 0 & 0 & 0 \\
\hline 2 & 15 & 15.35 & 32 & 34.52 & 20 & 20.43 & 0 & 0 & 0 & 0 \\
\hline 3 & 21 & 23.35 & 22 & 23.81 & 15 & 15.35 & 0 & 0 & 0 & 0 \\
\hline 4 & 16 & 16.48 & 17 & 17.86 & 14 & 14.90 & 0 & 0 & 0 & 0 \\
\hline 5 & 10 & 10.19 & 21 & 21.43 & 15 & 15.35 & 0 & 0 & 0 & 0 \\
\hline 6 & 18 & 18.67 & 24 & 26.19 & 4 & 4.38 & 0 & 0 & 0 & 0 \\
\hline 7 & 19 & 19.43 & 28 & 30.95 & 2 & 2.86 & 0 & 0 & 0 & 0 \\
\hline 8 & 20 & 20.29 & 27 & 28.57 & 2 & 2.86 & 0 & 0 & 0 & 0 \\
\hline 9 & 19 & 19.29 & 32 & 34.52 & 2 & 2.86 & 0 & 0 & 0 & 0 \\
\hline 10 & 10 & 10.19 & 22 & 23.81 & 5 & 5.67 & 0 & 0 & 0 & 0 \\
\hline Rata-Rata & 13 & 40.62 & 14 & 43.75 & 5 & 15.62 & 0 & 0 & 0 & 0 \\
\hline
\end{tabular}

Tabel 3.6 menunjukkan variabel Kinerja Guru sudah terlaksanakan dengan baik, dimana responden rata - rata yang menyatakan sangat setuju adalah sebanyak 13 orang atau sama dengan $40,62 \%$. Responden yang menyatakan setuju adalah sebanyak 14 orang atau sama dengan $43,75 \%$. Responden yang menyatakan kurang setuju adalah sebanyak 5 orang atau sama dengan $15,62 \%$.

\section{Pengujian Validitas dan Reliabilita}

Uji validitas dilakukan untuk mengukur tingkat kebenaran, kemampuan indikator dalam mengukur variabel, sedangkan uji reliabilitas untuk melihat kekonsistenan dari indicator dalam mengukur variabel yang diukurnya. Hasil uji validitas dan reliabilitas dapat dilihat pada tabel berikut ini:

Al Qalam: Jurnal Ilmiah Keagamaan dan Kemasyarakatan Vol. 16, No. 1 Januari - Juni 2022 
Rasman, Sofyan, Dedy Suhery, Syarifah Hanim : Pengaruh Disiplin dan Motivasi Terhadap Kinerja Guru di SMP Negeri 2 Kejuruan Muda Kabupaten Aceh Tamiang

\section{a. Disiplin}

Tabel 3.7 Uji Validitas Disiplin

\begin{tabular}{|c|c|c|c|}
\hline Item Kuesioner & $\mathbf{r}_{\text {hitung }}$ & $\mathrm{r}_{\text {tabel }}$ & Kesimpulan \\
\hline Kuesioner 1 & 0,621 & \multirow{10}{*}{0,349} & \multirow{10}{*}{ Valid } \\
\hline Kuesioner 2 & 0,503 & & \\
\hline Kuesioner 3 & 0,378 & & \\
\hline Kuesioner 4 & 0,652 & & \\
\hline Kuesioner 5 & 0,743 & & \\
\hline Kuesioner 6 & 0,701 & & \\
\hline Kuesioner 7 & 0,690 & & \\
\hline Kuesioner 8 & 0,683 & & \\
\hline Kuesioner 9 & 0,643 & & \\
\hline Kuesioner 10 & 0,521 & & \\
\hline
\end{tabular}

Tabel 3.7 menunjukkan seluruh indikator pada setiap variabel telah memenuhi syarat validitas, yaitu $r_{\text {hitung }}>r_{\text {tabel }}$. Oleh sebab itu, indikator - indikator tersebut dapat digunakan untuk mengukur variabel penelitian ini. Sedangkan pengujian reliabilitas dapat dilihat pada tabel berikut ini:

Tabel 3.8 Hasil Uji Reliabilitas Variabel Disiplin

\begin{tabular}{|l|l|l|l|}
\hline Variabel & $\begin{array}{l}\text { Cronbach } \\
\text { Alfa } \\
\text { Hitung }\end{array}$ & $\begin{array}{l}\text { Cronbach } \\
\text { Alfa Standar }\end{array}$ & Keputusan \\
\hline Disiplin & 0,752 & 0,600 & Realibel \\
\hline
\end{tabular}

Tabel 3.8 menunjukkan bahwa seluruh variabel Disiplin telah memenuhi syarat uji reliabilitas, dimana nilai Cronbach Alfa hitung lebih besar dari nilai Cronbach Alfa standar. Sehingga dapat disimpulkan bahwa indikator variabel Disiplin memiliki tingkat konsistensi yang baik dalam mengukur variable Disiplin.

\section{b. Motivasi}

Berdasarkan pada hasil olahan data, maka diketahui hasil uji validitas pada variabel Motivasi adalah sebagai berikut:

Tabel 3.9 Uji Validitas Motivasi

\begin{tabular}{|c|c|c|c|}
\hline Item Kuesioner & $r_{\text {hitung }}$ & $\mathrm{r}_{\text {tabel }}$ & Kesimpulan \\
\hline Kuesioner 1 & 0,723 & \multirow{6}{*}{0,349} & \multirow{6}{*}{ Valid } \\
\hline Kuesioner 2 & 0,614 & & \\
\hline Kuesioner 3 & 0,577 & & \\
\hline Kuesioner 4 & 0,708 & & \\
\hline Kuesioner 5 & 0,737 & & \\
\hline Kuesioner 6 & 0,731 & & \\
\hline
\end{tabular}

Al Qalam: Jurnal Ilmiah Keagamaan dan Kemasyarakatan Vol. 16, No. 1 Januari - Juni 2022 
Rasman, Sofyan, Dedy Suhery, Syarifah Hanim : Pengaruh Disiplin dan Motivasi Terhadap Kinerja Guru di SMP Negeri 2 Kejuruan Muda Kabupaten Aceh Tamiang

\begin{tabular}{|l|l|l|l|}
\hline Kuesioner 7 & 0,787 & \multirow{5}{*}{} & \\
\cline { 1 - 2 } Kuesioner 8 & 0,701 & \\
\cline { 1 - 2 } Kuesioner 9 & 0,727 & & \\
\cline { 1 - 2 } Kuesioner 10 & 0,692 & & \\
\hline
\end{tabular}

Tabel 3.9 menunjukkan seluruh indikator pada setiap variabel telah memenuhi syarat validitas, yaitu $r_{\text {hitung }}>r_{\text {tabel }}$. Oleh sebab itu, indikator - indikator tersebut dapat digunakan untuk mengukur variabel penelitian ini. Sedangkan pengujian reliabilitas dapat dilihat pada tabel berikut ini:

Tabel 3.10 Hasil Uji Reliabilitas Variabel Motivasi

\begin{tabular}{|l|l|l|l|}
\hline Variabel & $\begin{array}{l}\text { Cronbach } \\
\text { Alfa } \\
\text { Hitung }\end{array}$ & $\begin{array}{l}\text { Cronbach } \\
\text { Alfa Standar }\end{array}$ & Keputusan \\
\hline Motivasi & 0,768 & 0,600 & Realibel \\
\hline
\end{tabular}

Tabel 3.10 menunjukkan bahwa seluruh variabel Motivasi telah memenuhi syarat uji reliabilitas, dimana nilai Cronbach Alfa hitung lebih besar dari nilai Cronbach Alfa standar. Sehingga dapat disimpulkan bahwa indicator variabel Motivasi memiliki tingkat konsistensi yang baik dalam mengukur variabel Motivasi.

\section{c. Kinerja Guru}

Berdasarkan pada hasil olahan data, maka diketahui hasil uji validitas pada variabel Kinerja Guru adalah sebagai berikut:

Tabel 3.11 Uji Validitas Kinerja Guru

\begin{tabular}{|c|c|c|c|}
\hline Item Kuesioner & $\mathrm{r}_{\text {hitung }}$ & $\mathrm{r}_{\text {tabel }}$ & Kesimpulan \\
\hline Kuesioner 1 & 0,636 & \multirow{10}{*}{0,349} & \multirow{10}{*}{ Valid } \\
\hline Kuesioner 2 & 0,822 & & \\
\hline Kuesioner 3 & 0,707 & & \\
\hline Kuesioner 4 & 0,728 & & \\
\hline Kuesioner 5 & 0,807 & & \\
\hline Kuesioner 6 & 0,672 & & \\
\hline Kuesioner 7 & 0,593 & & \\
\hline Kuesioner 8 & 0,630 & & \\
\hline Kuesioner 9 & 0,515 & & \\
\hline Kuesioner 10 & 0,721 & & \\
\hline
\end{tabular}

Tabel 3.11 menunjukkan seluruh indikator pada setiap variabel telah memenuhi syarat validitas, yaitu $r_{\text {hitung }}>r_{\text {tabel }}$. Oleh sebab itu, indikator - indikator tersebut dapat digunakan untuk mengukur variabel penelitian ini. Sedangkan pengujian reliabilitas dapat dilihat pada tabel berikut ini:

Al Qalam: Jurnal Ilmiah Keagamaan dan Kemasyarakatan Vol. 16, No. 1 Januari - Juni 2022 
Rasman, Sofyan, Dedy Suhery, Syarifah Hanim : Pengaruh Disiplin dan Motivasi Terhadap Kinerja Guru di SMP Negeri 2 Kejuruan Muda Kabupaten Aceh Tamiang

Tabel 3.12 Hasil Uji Reliabilitas Variabel Kinerja Guru

\begin{tabular}{|l|l|l|l|}
\hline Variabel & $\begin{array}{l}\text { Cronbach } \\
\text { Alfa } \\
\text { Hitung }\end{array}$ & $\begin{array}{l}\text { Cronbach } \\
\text { Alfa Standar }\end{array}$ & Keputusan \\
\hline Kinerja Guru & 0,766 & 0,600 & Realibel \\
\hline
\end{tabular}

Tabel 3.12 menunjukkan bahwa seluruh variabel Kinerja Guru telah memenuhi syarat uji reliabilitas, dimana nilai Cronbach Alfa hitung lebih besar dari nilai Cronbach Alfa standar. Sehingga dapat disimpulkan bahwa indicator variable Kinerja Guru memiliki tingkat konsistensi yang baik dalam mengukur variabel Kinerja Guru. Penilaian pengaruh Disiplin $\left(\mathrm{X}_{1}\right)$, dan Motivasi $\left(\mathrm{X}_{2}\right)$ terhadap Kinerja Guru $(\mathrm{Y})$ dapat dilakukan dengan menggunakan analisis regresi berganda, yang dilakukan dengan SPSS. Model regresi linier berganda (multiple regression) dapat disebut sebagai model yang baik jika model tersebut memenuhi kriteria BLUE (best linear unbiased estimator). BLUE dapat dicapai bila memenuhi asumsi klasik.

\section{Uji Asumsi Klasik}

\section{Uji Normalitas}

Pada penelitian ini uji normalitas akan dideteksi melalui perhitungan regresi dengan SPSS dan uji statistik dengan menggunakan Uji One-Sample Kolmogorov-Smirnov (K-S) test. Normalitas residual diuji hipotesis sebagai berikut:

$$
\begin{array}{lll}
\mathrm{H}_{\mathrm{o}} & : & \text { residual terdistribusi dengan normal } \\
\mathrm{H}_{1} & : & \text { residual tidak terdistribusi dengan normal }
\end{array}
$$

Statistik uji yang digunakan adalah Uji One-Sample Kolmogorov-Smirnov (K-S) test. Kriteria yang digunakan adalah :

1) Terima Ho bila signifikan K-S $>\alpha(0.05)$

2) Tolak Ho bila signifikan K-S $<\alpha(0.05)$

Di samping menggunakan uji kolmogorov smirnove analisis kenormalan data ini juga didukung dari Plot of Regression Standaridized Residual. Apabila grafik yang diperoleh dari input SPSS ternyata titik-titik mendekati garis diagonal dapat disimpulkan bahwa model regresi berdistribusi normal. Lebih jelasnya hasil uji normalitas data dapat dilihat pada grafik berikut:

Tabel 3.13 Hasil Uji Normalitas

One-Sample Kolmogorov-Smirnov Test

\begin{tabular}{|ll|l|}
\hline & & $\begin{array}{l}\text { Unstandardized } \\
\text { Residual }\end{array}$ \\
\hline $\mathrm{N}$ & & 32 \\
Normal Parameters $\mathrm{a}, \mathrm{b}$ & Mean & $0 \mathrm{E}-7$ \\
& Std. Deviation & 1,23059846 \\
& Absolute &, 104 \\
Most Extreme Differences & Positive &, 098 \\
& Negative &,- 104 \\
Kolmogorov-Smirnov $Z$ & &, 591 \\
Asymp. Sig. (2-tailed) & &, 876 \\
\hline
\end{tabular}

Al Qalam: Jurnal Ilmiah Keagamaan dan Kemasyarakatan Vol. 16, No. 1 Januari - Juni 2022 
Rasman, Sofyan, Dedy Suhery, Syarifah Hanim : Pengaruh Disiplin dan Motivasi Terhadap Kinerja Guru di SMP Negeri 2 Kejuruan Muda Kabupaten Aceh Tamiang

a. Test distribution is Normal.

b. Calculated from data.

Berdasarkan hasil pengujian pada data output, dapat dijelaskan bahwa nilai Asymptotic Sinificance sebesar 0,876. Dengan dasar pengambilan keputusan, maka nilai $0,876>0,05$. Dari hasil pengujian SPSS dapat disimpulkan bahwa data-data yang diuji. Terdistribusi secara normal.

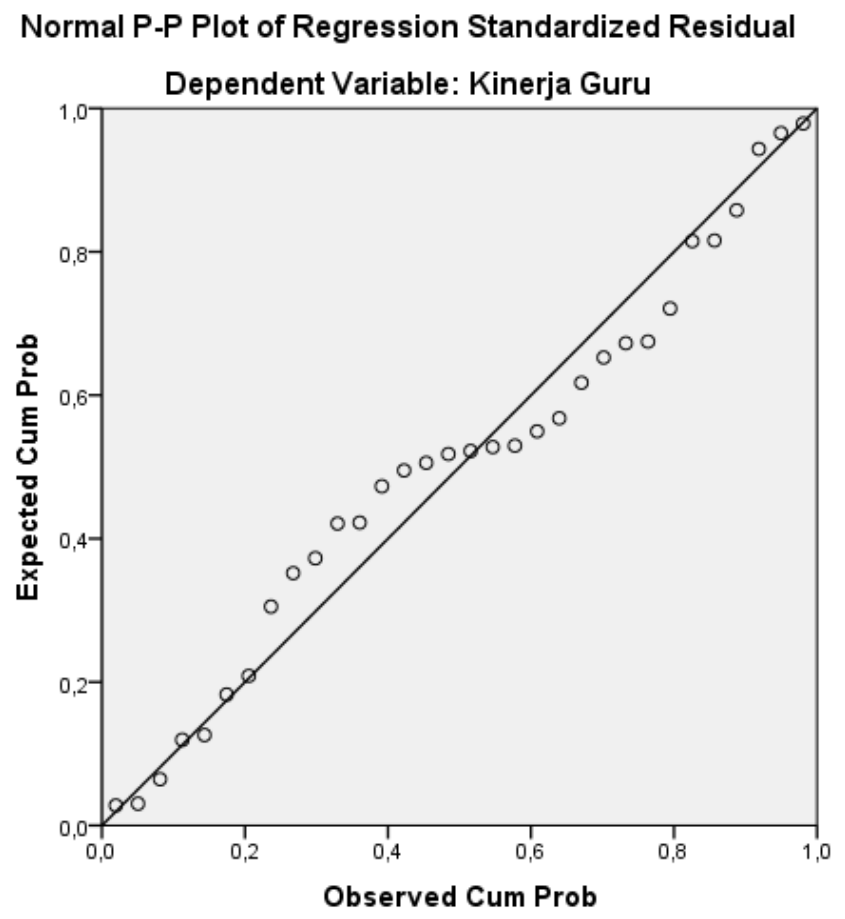

Gambar 3.1 Grafik Normalitas

Dari gambar di atas dapat dilihat bahwa persebaran data (titik) mengikuti arah garis diagonal, sehingga dapat disimpilkan bahwa gambar plot tersebut membuktikan bahwa model Regresi berdistribusi normal dan dapat melanjutkan penelitian. Apabila persebaran data (titik) tersebut mengikuti arah garis diagonal, sehingga dapat disimpulkan model rgresi berdistribusi normal dan dapat melanjutkan penelitian.

\section{Pembahasan}

\section{$\mathrm{H}_{1}$ : Disiplin berpengaruh positif dan signifikan terhadap Kinerja Guru}

Berdasarkan hasil pengolahan data diatas peneliti menentukan hasil dimana Disiplin $\left(\mathrm{X}_{1}\right)$ memiliki pengaruh terhadap Kinerja Guru (Y). Hal ini ditunjukan dengan hasil pengujian secara hipotesis pada variabel Disiplin $\left(\mathrm{X}_{1}\right)$, diperoleh nilai signifikansi adalah 0,000 yang bernilai kurang dari $\alpha=0,05$, oleh karena itu keputusan $\mathrm{H}_{1}$ diterima. Sehingga dapat disimpulkan bahwa variabel Disiplin $\left(\mathrm{X}_{1}\right)$ berpengaruh secara signifikan terhadap Kinerja Guru (Y). Sedangkan untuk nilai thitung pada Disiplin terdapat nilai yang positif terhadap $t_{t a b e l}$, sehingga dapat disimpulkan bahwa Disiplin berpengaruh positif dan signifikan terhadap Kinerja Guru.

Al Qalam: Jurnal Ilmiah Keagamaan dan Kemasyarakatan Vol. 16, No. 1 Januari - Juni 2022 
Rasman, Sofyan, Dedy Suhery, Syarifah Hanim : Pengaruh Disiplin dan Motivasi Terhadap Kinerja Guru di SMP Negeri 2 Kejuruan Muda Kabupaten Aceh Tamiang

\section{$\mathrm{H}_{2}$ : Motivasi berpengaruh positif tetapi tidak signifikan terhadap Kinerja Guru}

Berdasarkan hasil pengolahan data diatas peneliti menentukan hasil dimana Motivasi $\left(\mathrm{X}_{2}\right)$ tidak memiliki pengaruh terhadap Kinerja Guru $(\mathrm{Y})$. Hal ini ditunjukan dengan hasil pengujian secara hipotesis pada variabel Motivasi $\left(\mathrm{X}_{2}\right)$, diperoleh nilai signifikansi adalah 0,769 yang bernilai lebih besar dari $\alpha=0,05$, oleh karena itu keputusan $\mathrm{H}_{2}$ ditolak. Sehingga dapat disimpulkan bahwa variabel Motivasi $\left(\mathrm{X}_{2}\right)$ tidak berpengaruh secara signifikan terhadap Kinerja Guru (Y). Sedangkan untuk nilai $t_{\text {hitung }}$ pada Motivasi terdapat nilai yang positif terhadap tabel, sehingga dapat disimpulkan bahwa Motivasi berpengaruh positif tetapi tidak signifikan terhadap Kinerja Guru.

\section{$\mathrm{H}_{4}$ : Disiplin dan Motivasi berpengaruh secara signifikan dan simultan terhadap Kinerja Guru}

Berdasarkan hasil pengolahan data diatas peneliti menentukan hasil dimana Disiplin $\left(\mathrm{X}_{1}\right)$ dan Motivasi $\left(\mathrm{X}_{2}\right)$ berpengaruh secara signifikan dan simultan terhadap Kinerja Guru (Y). Hal ini ditunjukan dengan hasil pengujian hipotesis pada variabel Disiplin dan Motivasi diperoleh nilai signifikansi adalah 0,000 yang bernilai kurang dari $\alpha 0,05$, oleh karena itu keputusan adalah $\mathrm{H}_{4}$ diterima. Sehingga dapat disimpulkan bahwa variabel Disiplin dan Motivasi berpengaruh secara signifikan dan simultan terhadap Kinerja Guru.

\section{KESIMPULAN}

Berdasarkan pada penjelasan-penjelasan sebelumnya maka penelitian ini dapat disimpulkan sebagai berikut:

a. Terdapat pengaruh positif dan signifikan Disiplin terhadap Kinerja Guru SMP Negeri 2 Kejuruan Muda Kabupaten Aceh Tamiang sebesar 0,797 terhadap Kinerja Guru sehingga dapat di simpulkan Disiplin yang memadai dapat menentukan Kinerja Guru juga akan tinggi walaupun ada variable lain yang mendukung untuk melihat hasil kinerja seorang Guru .

b. Terdapat pengaruh positif tetapi tidak signifikan Motivasi terhadap Kinerja Guru SMP Negeri 2 Kejuruan Muda Kabupaten Aceh Tamiang sebesar 0,022 terhadap Kinerja Guru sehingga dapat di simpulkan Motivasi yang memadai dapat menentukan Kinerja Guru juga akan tinggi walaupun ada variabel lain yang mendukung untuk melihat hasil kinerja seorang Guru.

c. Secara simultan dapat dilihat bahwa variabel independen Disiplin, Motivasi dan Kompetensi memiliki nilai signifikan $\alpha(0,000<0,05$ dan nilai fhitung $>$ ftabel $(89,277$ $>3,32$ ). Sehingga dapat disimpulkan bahwa variabel Disiplin dan Motivasi berpengaruh secara signifikan dan simultan terhadap Kinerja Guru. Sehingga hal ini berarti semakin tinggi Disiplin, Motivasi dan Kompetensi semakin baik pula Kinerja Guru. Dan sebaliknya semakin rendah Disiplin dan Motivasi maka Kinerja Guru semakin kurang baik.

Al Qalam: Jurnal Ilmiah Keagamaan dan Kemasyarakatan Vol. 16, No. 1

Januari - Juni 2022 
Rasman, Sofyan, Dedy Suhery, Syarifah Hanim : Pengaruh Disiplin dan Motivasi Terhadap Kinerja Guru di SMP Negeri 2 Kejuruan Muda Kabupaten Aceh Tamiang

\section{DAFTAR PUSTAKA}

Anwar Prabu, Mangkunegara. Evaluasi Kinerja Sumber Daya Manusia. Bandung: PT Refika Aditama, 2009.

Arikunto. Metode Penelitian Pendidikan Pendekatan Kuantitatif, Kualitatif dan R\&D. Bandung: Alfabeta, 2002.

Bafadal, Ibrahim. Manajemen Perlengkapan Sekolah Teoridan Aplikasinya. Jakarta: Bumi Aksara, 2008.

Handoko. Manajemen. Vol. 2. Yogyakarta: BPFE, 2001.

Hasibuan. Organisasi Dan Motivasi Dasar Peningkatan Produktivitas. Vol. 7. Jakarta: Bumi Aksara, 2012.

- Proses Belajar Mengajar. Bandung: PT Rosda karya, 2011.

Hukumonline. "Undang-Undang Nomor 20 Tahun 2003 - Pusat Data Hukumonline." hukumonline.com. $\quad$ Diakses $13 \quad$ Januari 2022. https://hukumonline.com/pusatdata/detail/13662/undangundang-nomor-20-tahun2003/document.

Jackson, J.H dan Mathis, R.L. Human Resource Management: Manajemen Sumber Daya Manusia. Diterjemahkan oleh Dian Angelia. Jakarta: Salemba Empat, 2008.

Kunandar. Guru Profesional Implementasi Kurikulum Tingkat Satuan Pendidikan (KTSP) dan Persiapan Menghadapi Sertifikasi Guru. Jakarta: PT Raja Grafindo Persada, 2007.

Pandji, Anoraga. Psikologi Kerja. Jakarta: Rineka Cipta, 1998.

Robbins. Perilaku Organisasi Konsep Kontroversi Aplikasi. Edisi Bhs. Indonesia. Jakarta: PT. Prenhallindo, 2001.

Triton. Prosedur Penelitian Suatu Pendekatan Pratik. Jakarta: Rineka Cipta, 2002.

Warsidi dan Pramuka. Pemahaman Ekonomi Umum. Jakarta: PT. Gramedia Pustaka Umum, 2000.

Winardi, J. Manajemen Perilaku Organisasi. Jakarta: Kencana Prenada Media Group, 2004.

Al Qalam: Jurnal Ilmiah Keagamaan dan Kemasyarakatan Vol. 16, No. 1

Januari - Juni 2022 